Exp. Anim, 27 (2) $167-175,1978$

\title{
Comparative Studies on Lactate Dehydrogenase in Serum and Plasma of Rats
}

\author{
Toshihiro EMORI, Masakazu TAKAHASHI and Sumi NAGASE \\ Sasaki Institute, Surugadai, Chiyoda-ku Tokyo 101, Japan
}

(Received for publication: Oct. 12, 1977)

\begin{abstract}
Values of serum and plasma $\mathrm{LDH}$ in rats were comparatively studied, and the following results were obtained: 1) The activity of LDH increased in serum with time during clotting, but no changes of LDH activity were found in plasma. 2) When platelet rich plasma (PRP) was recalcified and allowed to clot, LDHrelease from platelets with a corresponding increase of serum LDH was observed, but addition of ADP or thrombin to PRP did not have an effect on LDH-release. 3) LDH-release from platelets by calcium was not inhibited by aspirin, and it was influenced by the quality of the test tube. 4) Values of serum and plasma LDH on experimentally induced liver-damaged or kidney-damaged rats and tumor-bearing rats were examined in relation to their tissue damages, revealing that plasma LDH activity represents the condition of a disease better than serum LDH activity.
\end{abstract}

\section{ラット血清および血漿乳酸脱水素酵素の比較検討}

\author{
江守利博・高橋正一・長瀬すみ \\ 佐々木研究所
}

\begin{abstract}
近年, 毒性テストや疾患モデルに, 実験動物としてラ ットが多く用いられ，またそれらの血液生化学的データ の必要性が増加している。しかし，ヒトと同粎の測定条 件で得た結果には, 種々問題点が残され，それらに関す る検討が望まれている。特にラットの血清 LDH 活性が, 人を含む他の動物種に比べ非常に高く, またバラッキも 大であり, 臓器の障害の程度との相関が必ずしも明確で ない点などが指摘されてきた。また近年，FRIEDEL 等 [1]は，ヒト，イヌ、ウサギ，ラットを用いて数種 の酵素に関して血清, 血漿の活性值を比較し, 特にラッ
\end{abstract}

略字の説明

ADP : Adenosine-5'-diphosphate

BUN : Blood Urea Nitrogen

LDH : Lactate Dehydrogenase

PRP : Platelet Rich Plasma
トの血清 LDH 活性が採血から血清分離むでの放置時間 とともに増大すること，またその原因が血液凝固過程時 に崩買される血小板からの LDH の放出によるものであ ることを報告している。そこで我々はこの点をさらに詳 細に検討するとともに，各種病態モデルを作成し，血 清, 血墏のいら゙れが病態の程度をより良く反映するかを 検討し，若干の知見を得たので報告する。

\section{材料および方法}

1）血清，血漿及び Platelet Rich Plasma（以下 PR $\mathrm{P}$ と略す)の分離 : ラットをエーテル麻酔後, 腹部大動 脈より採血し，経時的実験以外は 1 時間室温放置後血清 または血漿に分離した。なお血漿はへパリン血（25U/ $\mathrm{ml}$ blood）上り分離した。PRP は血液 9 に対し，3.8 
\%クエン酸ナトリウム液を 1 の割合で加え， $150 \times \mathrm{g}$, 10 分遠心により得た。また採血は, 経時的実験を含む 為, すべて非絶食の条件で行なった。

2） LDH 及び BUN の測定 : LDH はベーリンガー社 の測定キット（UV 法）を用い，LKB 8600 型にて測定 した。BUN はジアセチルモノオキシム法により測定し た。また LDH アイソザイムは, ヘレナ社の Titan III セルロースアセテート膜を用い, ベロナール緩衝液 $(\mathrm{pH}$ 8.6) で， $180 \mathrm{~V} ， 40$ 分泳動後，フォルマザンの発色を行 なった。

3）四塩化炭素による急性肝障害：JCL-SD ラット, 5 週令, 雄を各群 5 匹使用した。 $50 \%$ 四塩化炭素（オリ 一ブ油に溶解）を $4 \mathrm{ml} / \mathrm{kg}$ 経口投与し，投与後， 2 ，

$4,6,24$ 時間目に採血, 血清または血漿に分離し LD $\mathrm{H}$ 活性を測定した。

4）塩化第二水銀による急性腎障害：JCL-SD ラット, 15週令, 雄を各群 5 匹使用した。塩化第二水銀を $3 \mathrm{mg} /$ $\mathrm{kg}$ 筋肉内投与し，投与後 $2,4,6,24$ 時間目に採血, 血清または血漿に分離し LDH 及び BUN を測定した。 5）腹水肝癌移殖：Donryu ラット， 8 週令，雄を各 群 5 匹使用した。吉田肉腫細胞を 1 匹あたり $1 \times 10^{6}$ 個 腹腔内に移殖し, 移殖後 $2,4,6,7$ 日目に採血, 血 清または血漿の LDH 活性を測定した。

6）アスピリンによる血小板凝集阻害：JCL-SD ラット, 8 週令, 雌を各群15匹使用した。アスピリンを $50 \mathrm{mg} / \mathrm{kg}$ 及び $100 \mathrm{mg} / \mathrm{kg}$ 経口投与し, 投与後 90 分に採血, 血清 または血漿の LDH 活性を測定した。

7）血小板凝集時の LDH 放出：PRP $200 \mu 1$ に, 各々, $0.025 \mathrm{M}$ の $\mathrm{CaCl}_{2}, 1 \times 10^{-4} \mathrm{M}$ の $\mathrm{ADP}$ (シグマ社), $2 \mathrm{U} / \mathrm{ml}$ のトロンビン(ミドリ十字) の濃度に生理食塩液 に溶解したものを $100 \mu 1$ 添加し, $37^{\circ} \mathrm{C}$ で所定の時間そ れぞれインキュベーション後， $2000 \times \mathrm{g}, 10$ 分遠心し， その上清の $\mathrm{LDH}$ 活性を測定した。なお，PRP 中の血 小板数は実験毎で異なるが, $100 〜 150$ 万 $/ \mathrm{mm}^{3}$ の間で行 なった。

\section{成}

JCL-SD ラット， 5 週令，雌を10匹使用し，血清 L $\mathrm{DH}$ 活性に及ぼす血清または血漿分離までの全血放置時 間の影響を検討した。その結果, Fig. 1 に示すように, 血 清 $\mathrm{LDH}$ 活性は全血放置時間とともに上昇するのに対し， 血墏の場合はほぼ一定值を保ち，1時間放置後分離した 血清の LDH 活性值は血漿の約10１5倍の值を示した。

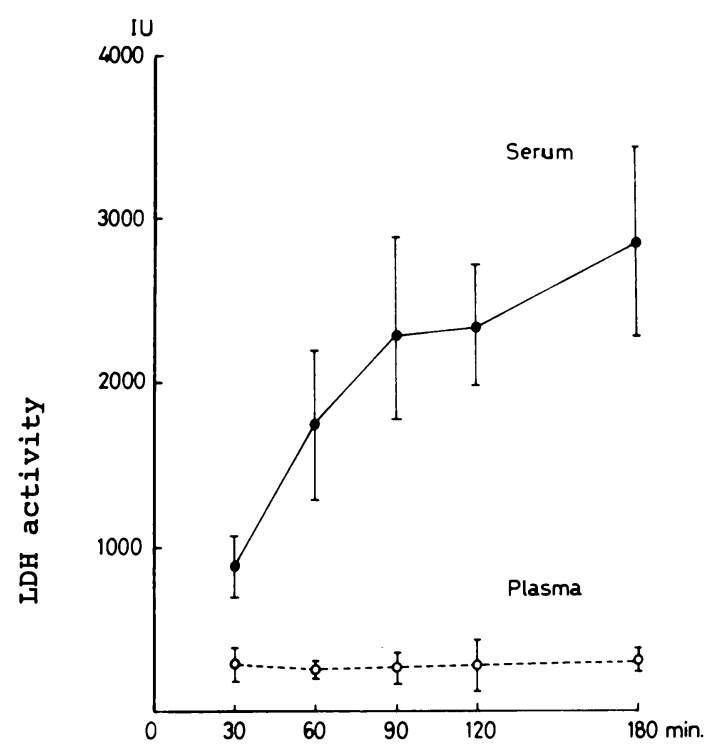

Fig. 1. Lactate dehydrogenase activity in serum and plama of rats, variation with time between drawing of blood and preparation of serum and plasma.

Rats : Female JCL-SD rats of 5 weeks of age. Each value represents average of 5 rats with a standard devia. tion.

このようにラットの LDH 活性値は血清と血漿で著しく 相違することを認めたので，次に各種病態モデルを作成 し, 血清, 血漿のいづれが病態の程度をより良く反映す るかを検討した。

まず，四塩化炭素による急性肝障害について検討した。 その結果，Fig. 2, Table 1 に示すように血清の場合 投与後24時間にならないと活性の上昇している個体が認 められないが（ 4 例中 2 例)，血漿では 4 時間で 5 例中 3 例， 6 時間以降では全例に活性の上昇を認めた。また 同時にLDH アイソザイムを検討した結果，血清，血漿 いづれも活性上昇を示したラットでV型（肝型）の增加 が認められた。

また塩化 第二水銀による急性腎障害 では，Fig. 3, Table 2 に示すように，血清の場合 24 時間でも活性の 上昇している個体を認めず，血寢の場合でも 5 例中 2 例 にとどまった。それに対し血清 BUN 值は24時間で全例 において上异を認めた（Fig. 4)。また LDH アインザ イムでは， 24 時間の血漿で活性上昇を示した 2 例 (No. 3. 5) で, 血清, 血漿いづれも I, II 型の出現が認めら 


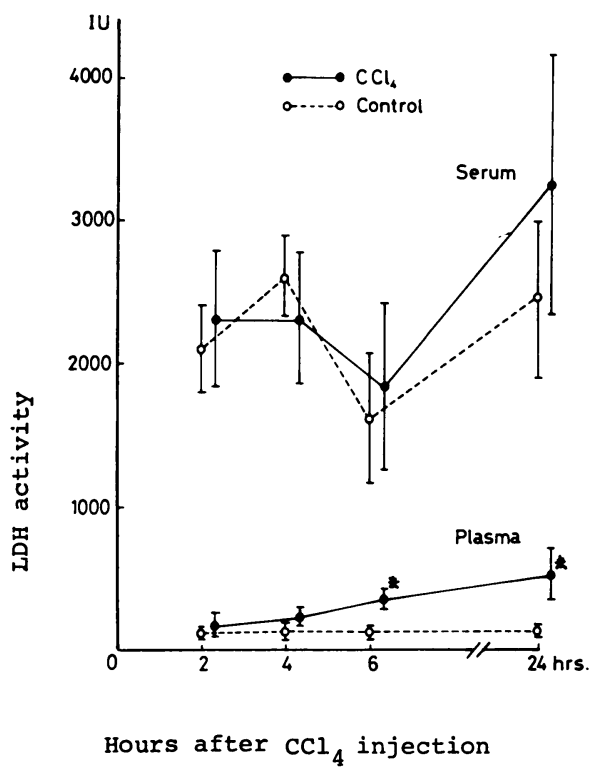

Fig. 2. Serum and plasma lactate dehydrogenase activity in rats with $\mathrm{CCl}_{4}-$ induced acute hepatic damage.

Route of Administration : i. p.

Dose : $4.0 \mathrm{ml} / \mathrm{kg}$ (The $\mathrm{CCl}_{4}$ was a 50 $\%$ solution with olive oil)

Rats : Male JCL-SD rats of 5 weeks of age

$* \mathrm{P}<0.01$



Fig. 3. Serum and plasma lactate dehydrogenase activity in rats with $\mathrm{HgCl}_{2_{2}}$ induced acute renal damage.

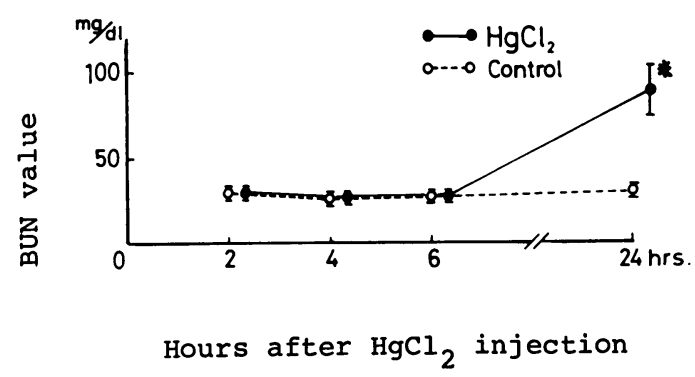

Fig. 4. Serum blood urea nitrogen value in rats with $\mathrm{HgCl}_{2}$-induced acute renal damage.

Route of Administration : i. m.

Dose : $30 \mathrm{mg} / \mathrm{kg}$

Rats : Male JCL-SD rats of 15 weeks of age

$* \mathrm{P}<0.01$

れた。また 2 及び 4 時間の血漿で高值を示すものについ ては，24時間の場合と異なり，III，IV型のアイソザイム が增加しており，注射部位の組織からの漏出と思われる。 なお、コントロール群の最高值よりも高値のものを上昇 していると判定した。

さらに吉田肉腫を移殖した場合 Fig.5に示したよらに, 血清では 7 日目の末期の及著しい活性上昇が認められた のに対して, 血漿では 6 日目の時点でコントロール（非 移殖）に対し平均值で約 2 倍の活性上昇を示し， 7 日目 では血清と同程度の活性の上异が認められた。以上の実 験結果により, 血清よりも血漿の方が早期に病態を反映 すると思われる。

次に Friedel[1]等が指摘するよ5に, 血清 LDH 活 性の上界が血液凝固時の血小板の崩壊によるのであれば, 血小板機能に影響を及ぼす薬物を投与した場合，血清 LDH 活性に何らかの影響を及ぼすことが考えられる。 そこで血小板凝集を阻害する薬物としてよく知られてい るアスピリンを投与した。その結果，Fig.6に示したよ 5に, $50 \mathrm{mg} / \mathrm{kg}$ 及び $100 \mathrm{mg} / \mathrm{kg}$ 投与群のいづれの場 合にも, 血清, 血將の LDH 活性にコントロール群との 有意な差を認めなかった。

このよらにアスピリンにより血小板凝集を阻害した場 合でも血清 $\mathrm{LDH}$ 活性に影響を及ぼさないことから，血 液凝固過程時の血小板からの LDH 放出のメカニズムに ついて若干の検討を行ないたいと考え，PRP に血小板 凝集あるいは凝固作用を有する物質を加えた際の血小板 からのLDH放出について検討した。その結果，Fig. 7 に 示したように, 単独では血小板凝集能を持たず疑固作用 
Table 1. Serum and plasma lactate dehydrogenase activity in rats with $\mathrm{CCl}_{4}$-induced acute hepatic damage

\begin{tabular}{|c|c|c|c|c|c|c|c|c|c|}
\hline & Animal No. & \multicolumn{2}{|c|}{$\begin{array}{c}2 \text { hours } \\
\text { Serum Plasma }\end{array}$} & \multicolumn{2}{|c|}{$\begin{array}{c}4 \text { hours } \\
\text { Serum Plasma }\end{array}$} & \multicolumn{2}{|c|}{$\begin{array}{c}6 \text { hours } \\
\text { Serum Plasma }\end{array}$} & \multicolumn{2}{|c|}{$\begin{array}{c}24 \text { hours } \\
\text { Serum Plasma }\end{array}$} \\
\hline \multirow{6}{*}{ Control } & 1 & 2433 & 108 & 2284 & 101 & 2011 & 108 & 1596 & 93 \\
\hline & 2 & 2476 & 104 & 2214 & 110 & 2109 & 131 & 2778 & 137 \\
\hline & 3 & 1848 & 97 & 2990 & - & 759 & 102 & - & 144 \\
\hline & 4 & 1955 & 150 & - & 84 & 1589 & 91 & 3176 & - \\
\hline & 5 & 1843 & 182 & 2734 & 199 & 1520 & 111 & 2274 & 122 \\
\hline & $\begin{array}{l}\text { Mean } \\
\text { S. D. }\end{array}$ & $\begin{array}{r}2111 \\
283\end{array}$ & $\begin{array}{r}128 \\
33\end{array}$ & $\begin{array}{r}2605 \\
280\end{array}$ & $\begin{array}{r}123 \\
45\end{array}$ & $\begin{array}{r}1597 \\
479\end{array}$ & $\begin{array}{r}108 \\
17\end{array}$ & $\begin{array}{r}2456 \\
590\end{array}$ & $\begin{array}{r}124 \\
19\end{array}$ \\
\hline \multirow{6}{*}{$\mathrm{CCl}_{4}$} & 1 & 3172 & 130 & 2748 & 307 & 2542 & 444 & 3600 & 497 \\
\hline & 2 & 2214 & 113 & 2175 & 152 & 1391 & - & 2642 & 297 \\
\hline & 3 & 2081 & 131 & 2990 & 166 & 2413 & 294 & - & - \\
\hline & 4 & 1898 & 118 & 1710 & 224 & 931 & 297 & 4578 & 734 \\
\hline & 5 & 2142 & 133 & 1952 & 273 & 1781 & 373 & 2170 & 615 \\
\hline & $\begin{array}{l}\text { Mean } \\
\text { S. D. }\end{array}$ & $\begin{array}{r}2301 \\
501\end{array}$ & $\begin{array}{r}125 \\
9\end{array}$ & $\begin{array}{r}2294 \\
489\end{array}$ & $\begin{array}{r}224 \\
61\end{array}$ & $\begin{array}{r}1811 \\
609\end{array}$ & $\begin{array}{r}352 \\
61\end{array}$ & $\begin{array}{r}3247 \\
926\end{array}$ & $\begin{array}{l}536 \\
186\end{array}$ \\
\hline
\end{tabular}

Table 2. Serum and plasma lactate dehydrogenase activity in rats with $\mathrm{HgCl}_{2}$-induced acute renal damage

\begin{tabular}{|c|c|c|c|c|c|c|c|c|c|}
\hline & Animal No. & \multicolumn{2}{|c|}{$\begin{array}{c}2 \text { hours } \\
\text { Serum Plasma }\end{array}$} & \multicolumn{2}{|c|}{$\begin{array}{l}4 \text { hours } \\
\text { Serum Plasma }\end{array}$} & \multicolumn{2}{|c|}{$\begin{array}{c}6 \text { hours } \\
\text { Serum Plasma }\end{array}$} & \multicolumn{2}{|c|}{$\begin{array}{c}24 \text { hours } \\
\text { Serum Plasma }\end{array}$} \\
\hline \multirow{6}{*}{ Control } & 1 & 1177 & 184 & 2454 & 110 & 1116 & 177 & 1518 & 112 \\
\hline & 2 & 1668 & 95 & 1102 & 153 & 2546 & 124 & 1125 & 135 \\
\hline & 3 & 1523 & 129 & 1710 & 126 & 1590 & 169 & 1555 & 121 \\
\hline & 4 & 2213 & 164 & 1884 & 107 & 1394 & 107 & 1489 & 111 \\
\hline & 5 & 2761 & 142 & 1575 & 110 & 1354 & 138 & 1197 & 116 \\
\hline & $\begin{array}{l}\text { Mean } \\
\text { S. D. }\end{array}$ & $\begin{array}{r}1868 \\
557\end{array}$ & $\begin{array}{r}143 \\
30\end{array}$ & $\begin{array}{r}1745 \\
439\end{array}$ & $\begin{array}{r}121 \\
17\end{array}$ & $\begin{array}{r}1600 \\
496\end{array}$ & $\begin{array}{r}143 \\
30\end{array}$ & $\begin{array}{r}1377 \\
179\end{array}$ & $\begin{array}{r}119 \\
9\end{array}$ \\
\hline \multirow{6}{*}{$\mathrm{HgCl}_{2}$} & 1 & 1897 & 493 & 2705 & 310 & 2228 & 144 & 2332 & 166 \\
\hline & 2 & 1851 & 175 & 2142 & 205 & - & - & 954 & 153 \\
\hline & 3 & 1621 & 125 & 1395 & 148 & 2074 & 123 & 1163 & 447 \\
\hline & 4 & 1667 & 211 & 1196 & 295 & 1363 & 116 & 825 & 144 \\
\hline & 5 & 2137 & 347 & 1899 & 158 & 1556 & 156 & 1747 & 870 \\
\hline & $\begin{array}{l}\text { Mean } \\
\text { S. D. }\end{array}$ & $\begin{array}{r}1834 \\
184\end{array}$ & $\begin{array}{l}270 \\
134\end{array}$ & $\begin{array}{r}1867 \\
539\end{array}$ & $\begin{array}{r}223 \\
68\end{array}$ & $\begin{array}{r}1805 \\
357\end{array}$ & $\begin{array}{r}135 \\
16\end{array}$ & $\begin{array}{r}1404 \\
561\end{array}$ & $\begin{array}{l}356 \\
281\end{array}$ \\
\hline
\end{tabular}

のみを有するカルシウムを添加した場合，経時的に LD $\mathrm{H}$ の放出が認められ，60分でほぼ血清 $\mathrm{LDH}$ 活性（1時 間放置後分離した血清）と同程度の活性が認められた。 それに対して血小板凝集能のみを有する ADP では軽度 にしか放出が認められなかった。さらに血小板凝集と凝 固作用の両作用を有するトロンビンでは，可視的に非常
に強い凝縮塊を形成するにもかかわらず，ほとんど LD $\mathrm{H}$ の放出が認められなかった。なおデータには示さない が，カルシウム，ADP 及びトロンビンは，実験に使用 した濃度では LDH 活性に影響を与えないことを確認し ている。

さらに，このカルシウムによる LDH の放出に対し， 


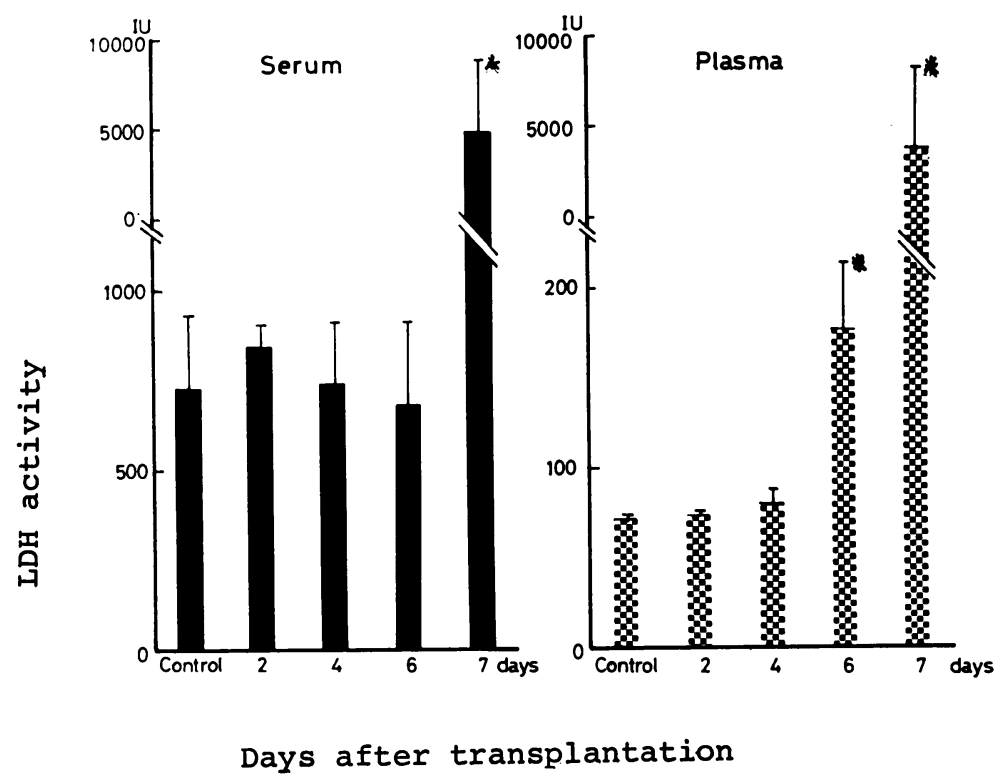

Fig. 5. Serum and plasma lactate dehydrogenase activity in rats Transplanted with Yoshida sarcoma.

Yoshida Sarcoma were transplanted intraperitoneally in a number of $1 \times 10^{6}$ cells per one body.

Rats : Male Donryu rats of 8 weeks of age

* $\mathrm{P}<0.01$
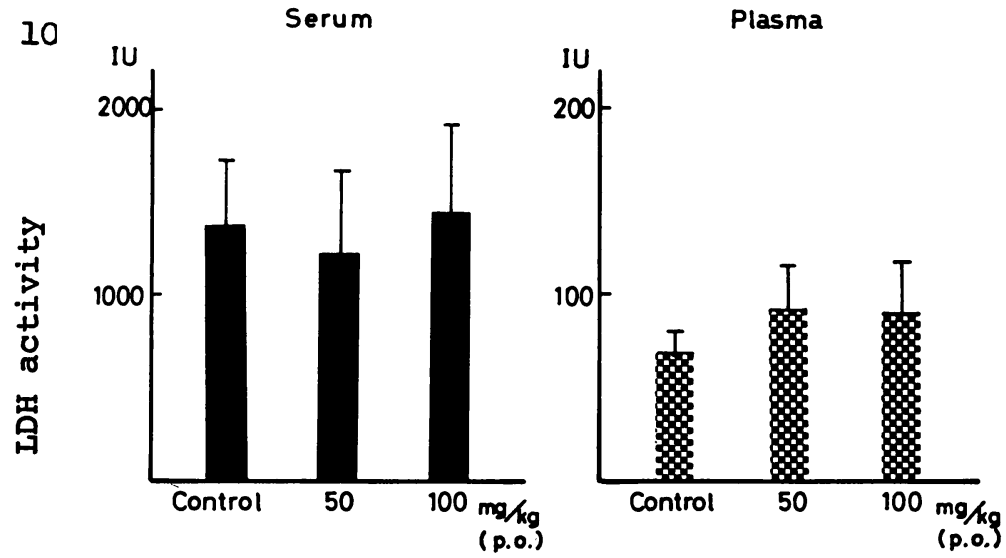

Fig. 6. Effect of aspirn on serum and plasma lactate dehydrogenase activity in rats.

Route of Administration : p. 0 .

Dose : $50 \mathrm{mg} / \mathrm{kg}$ or $100 \mathrm{mg} / \mathrm{kg}$

Rats : Female JCL-SD rats of 8 weeks of age 


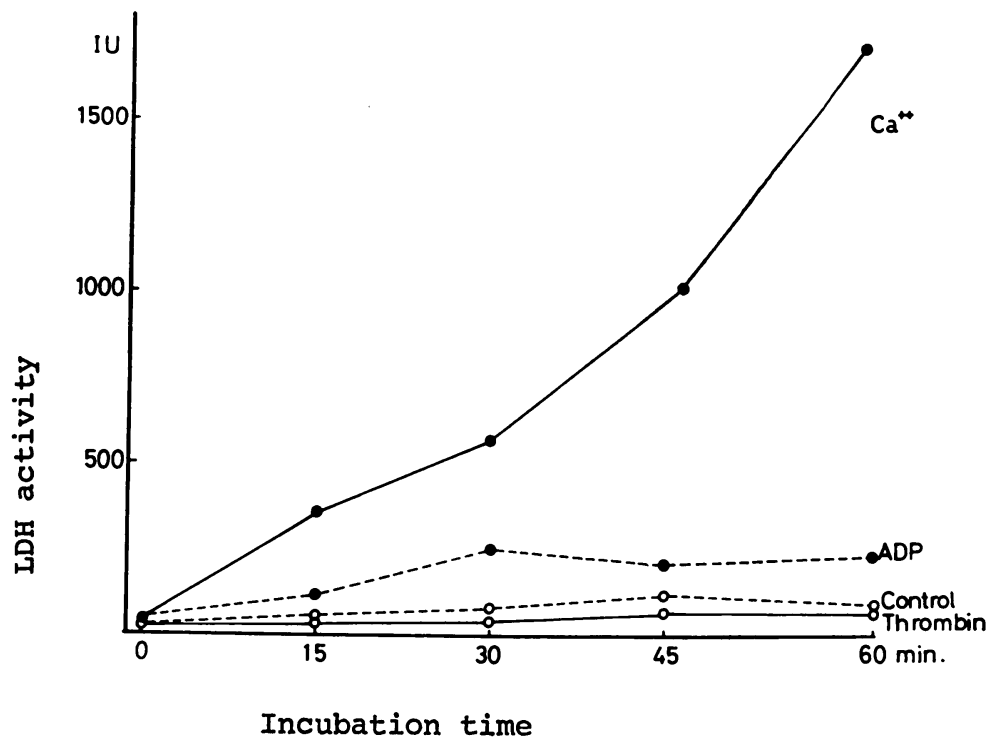

Fig. 7. Lactate dehydrogenase of platelet rich plasma before and after clotting.

$0.025 \mathrm{M} \mathrm{CaCl}_{2}, 1 \times 10^{-4} \mathrm{M}$ Adenosine-5'-diphosphate, $2 \mathrm{U} / \mathrm{ml}$ Thrombin and Saline as a control were added to PRP. Each sample was incubated for $0,15,30,45,60 \mathrm{~min}$. at $37^{\circ} \mathrm{C}$. After incubation, the reaction was stopped in a ice bath and then centrifuged at $1500 \times \mathrm{g}$ for $15 \mathrm{~min}$. LDH activity in the supernatant was measured.

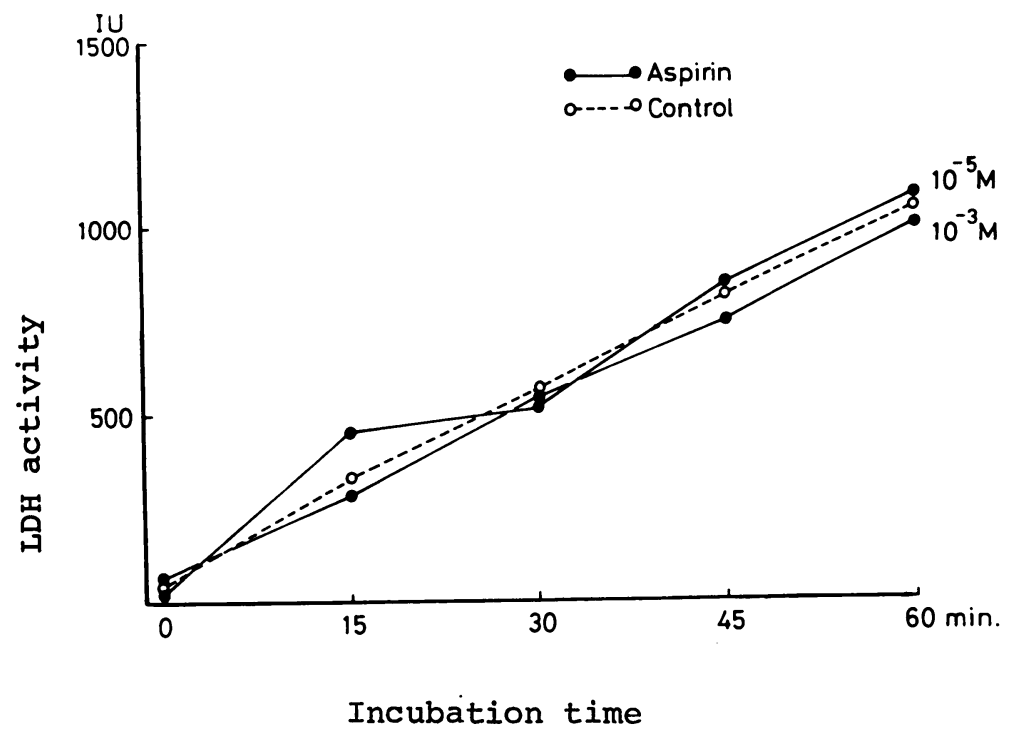

Fig. 8. Effect of aspirin on LDH-release from platelets during PRP Clotting by Calcium

$100 \mu 1$ of $0.025 \mathrm{M} \mathrm{CaCl}$ containing $1 \times 10^{-3} \mathrm{M}$ or $1 \times 10^{-5} \mathrm{M}$ Aspirin was added to $200 \mu \mathrm{l}$ of PRP. The samples were incubated for 0 , $15,30,45,60 \mathrm{~min}$. at $37^{\circ} \mathrm{C}$. After incubation, the reaction was stopped in a ice bath and then centrifuged at $1500 \times \mathrm{g}$ for $10 \mathrm{~min}$. $\mathrm{LDH}$ activity in the supernatant was measured. 


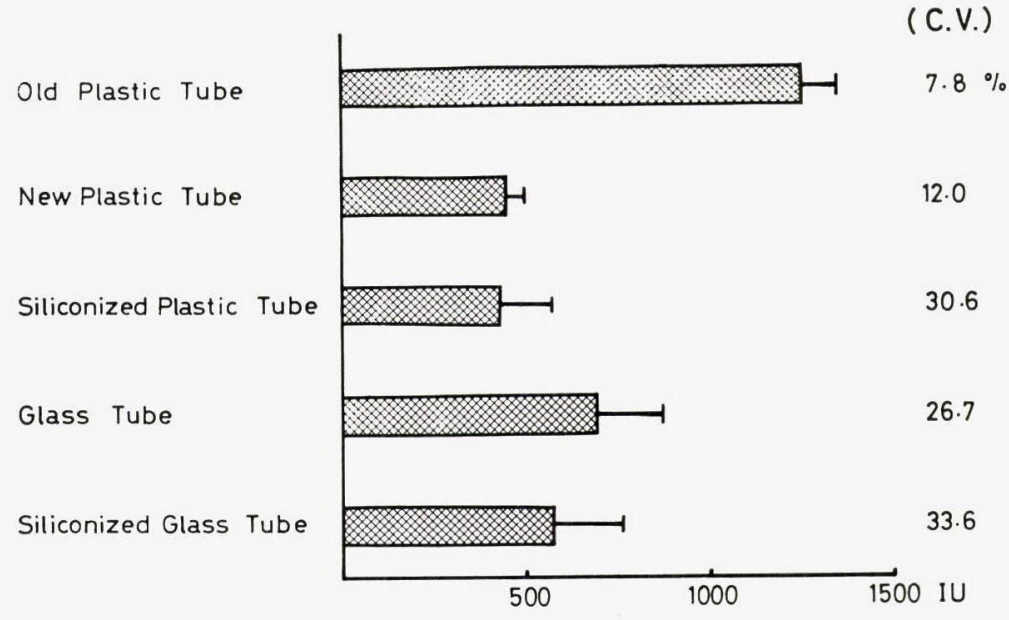

LDH activity

Fig. 9. Lactate dehydrogenase activity after PRP clotting by calcium using different kinds of test Tube.

$\mathrm{LDH}$ activity was measured at $60 \mathrm{~min}$. after addition of $0.025 \mathrm{MCaCl}_{2}$. C. V. : Coefficient of variation $(n=10)$.

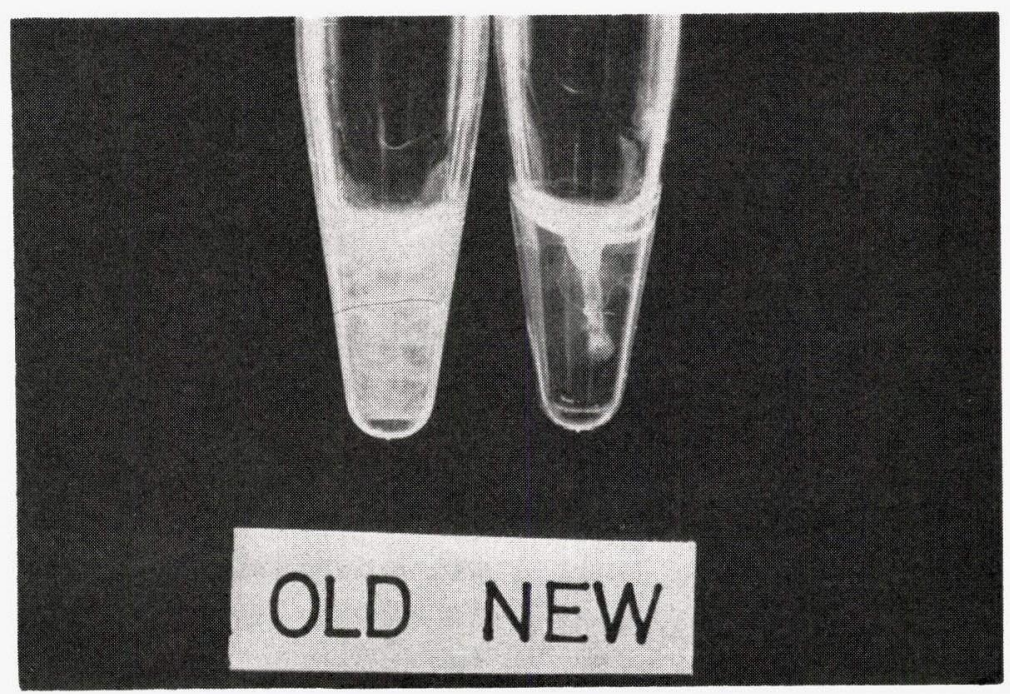

Fig. 10. A picture of fibrin clot in the PRP after cotting by addition of calcium.

Right: New plastie tube

Left : Old plastic tude 
in vitroでのアスピリンの効果を検討したところ，103$\mathrm{M}$ 及び $10^{-5} \mathrm{M}$ でも影響が慧められなかった（Fig. 8)。

またここのルシウムによる LDH の放出が，用いる 容器の材質により大きく左右されることを偶然見出した ので, その点について検討した。その結果，カルシウム 添加後60分の時点で， Fig. 9 に示すよ5に古いプラス チック試験管に此べ，新しいプラスチック試験管，ある いはガラス試験管及びシリコン処理した試験管では LD $\mathrm{H}$ の放出が少ないことを認めた。さらにプラスチック試 験管に比べ，ガラスやシリコン処理したものでは変動係 数からも明らかなよらにバラッキが大きいといら結果が 得られた。なお Fig. 7 及び Fig. 8 の実験は古いプラ スチック試験管を使用した結果である。

またFig. 10 に示したよらに，古いプラスチック試験 管に比べ新しいプラスチック試験管の場合，強く小さい 凝縮塊を形成し，ガラスやシリコン処理した試験管，あ るいはトロンビン添加時にも同様の強い凝縮塊を認め, 強く小さい凝縮塊の方が LDH の放出が少ないといら傾 向が認められた。

なお，新しいプラスチック試験管として，市販の滅莉 済の製品を洗沙しないで使用し，古いプラスチック試験 管として，10回以上洗滌したものを使用した。

\section{考察}

最初にも述べたように，FRIEDEL 等はラットの血 清 LDH 活性が血清分離までの放置時間とともに增大す ることを報告しており，我々も今回それを追試したとこ ろ，同様の結果を得た。すなわち血漿では放置時間に関 係なく一定値を 示すが，血清の場合，血液放置時間が $\mathrm{LDH}$ 活性值に大きく影響し，従来指摘されていたLDH のバラッキの大きな原因をなしていたと考えられる。

また，FRIEDEL 等はこの血清 LDH 活性の上㫒の 原因として，PRP 及び血漿にカルシウムを加え凝固さ せた場合，血寢では変化せず，PRP の場合に LDH 活 性が上昇することから，血小板の崩壊によるとしており， 我々もカルシウムを添加したところ同様の結果を得た。 しかし ADPにより血小板疑集のみを起こさせた結果， あるいはアスピリンによる in vivo, in vitro で血小 板凝集を阻害した場合の実験結果から明らかなように, 血小板からの LDH の放出は凝集過程には直接関係せず, 凝固過程に関係していることが示唆された。しかし凝固 過程に関係するとしても，トロンビンによる凝固時には ほとんど放出されず，またカルシウムによる放出も用い
る容器の材質により大きく影響される結果を得た。この 様に凝固時の血小板からの LDH 放出のメカニズムに関 してはなお検討の余地が残されている。しかし強く小さ い凝縮塊を形成した場合に放出が少ないことから，フィ ブリン網に LDH 分子がトラップされる可能性が示唆さ れ，血液の場合には赤血球が多数存在する為， PRP の 場合のよらに強く小さい凝縮塊を形成することができず， フィブリン網がゆるくなる結果, LDH 分子が血清中に 遊離すると考学ることもできる。なお血小板の LDH 了 イソザイムは血清, 血漿と同じV型であった。さらに, このよらな血小板からの LDH 放出が，なぜラットに著 明に生ずるのかといら点に関しては今のところ不明であ り, ラット血小板の特殊性についても今後検討の必要が あると考えられる。

また我々は各種病態モデルを作成し，血清，血漿のい づれがより良く病態を反映するかを検討したところ，我 々の行なった実験範囲では血漿の方が早期に病態を反映 する結果を得た。

以上のことから，毒性テスト等において，ラットの L DH 活性を測定する場合，血清では採血後分離までの時 間を一定にしなければならず，また血漿の方が病態の程 度を早期に 反映すること，及び凝固時の 血小板からの $\mathrm{LDH}$ 放出に多くの要因が働きバラツキの原因となるこ と等を考㦄すれば，血漿で行なら方が良いと考えられ る。今後, 血小板からの LDH 放出に凝固過程が関係す ることから, 凝固機能の異常の際の血清, 血漿の $\mathrm{LDH}$ 活性について検討するとともに，LDH 以外の項目につ いても検索を行なら予定である。な揾小板以外の血 球, すなわち赤血球, 白血球からの LDH の放出の可能 性については，赤血球からはほとんど放出されないこと を確認しているが，白血球については，白血球のみを単 離することが困難であるため検討できなかった。

ヒトの日常の臨床検査業務の範囲においては, 特殊検 査を除き，血清を使用するのが常であるが，ラットのみ ならず他の実験動物に関しても，よりよきパラメーター を得, 動物実験で得た成績を我々人類に活かすために, この方面の検討をさらに多項目について行なら必要があ るものと思われる。

\section{要 約}

疾患モデルや毒性テストに多くのラットが用いられ， それらの生化学的データが要求される事が多いが，それ らに関しての問題点は多く, 早急の解決が迫られてい 
る。バラッキの多いラット血清 LDH の原因究明の一端 として，血清及び血漿 LDH について比較検討を行ない 次の結果を得た。

1）血清 $\mathrm{LDH}$ 活性は血清分離までの血液放置時間とと もに増大するが，血漿では一定值を保った。

2） PRP にカルシウムを添加することにより，血清 L $\mathrm{DH}$ 活性の上昇を説明しらる血小板からの $\mathrm{LDH}$ 放出を 認めたが，ADP,トロンビンでは認められなかった。 3）このカルシウムによる血小板からの LDH 放出は了 スピリンによって阻害されなかったが, 使用する容器の
材質により大きく影響を受けた。

4）種々の病態モデルを作成し，血清または血漿の LD $\mathrm{H}$ 活性を検討したところ, 血漿の方が早期に病態を反映 する成績を得た。

\section{文献}

1 Fridel R. and Mattenheimer H. (1970): Release of metabolic enzymes from platelets during blood clotting of man, dog, rabbit and rat. Clin. Chim. Acta. 30 . $37-46$. 